\title{
Variation in the composition of breast milk during the first 5 weeks of lactation: implications for the feeding of preterm infants
}

\author{
C M HIBBERD, O G BROOKE, N D CARTER, M HAUG, AND G HARZER \\ Department of Child Health, St George's Hospital Medical School, London, and \\ Department of Research, Milupa AG, Friedrichsdorf, W Germany
}

SUMMARY Milk samples were collected from 10 mothers by a standardised technique with complete expression of both breasts at each feed for 24 hours. Samples were obtained at 8 intervals during the first 36 days of lactation. Analyses were performed for trichloroacetic acid-precipitable protein, total protein, lactose, triglycerides, phospholipids, cholesterol, energy, sodium, potassium, calcium, magnesium, zinc, copper, $\mathrm{pH}$, and osmolality. The results give a comprehensive picture of the development of milk composition from transitional to mature milk. The most striking feature of the results was the high degree of variation observed both between samples from the same mother and between samples from different mothers on the same day of lactation.

The variability of the composition of human milk is well known. Not only does the concentration of many nutrients change as lactation progresses ${ }^{1-3}$ but milk composition also varies between women, ${ }^{23}$ between the beginning and end of a feed, ${ }^{4}$ and between reflex drip milk and expressed milk. ${ }^{5}$ This variability is seldom critical for term infants but could result in inadequate nutrition in preterm infants fed with breast milk. Human milk is advocated by several authorities for feeding preterm infants, especially those who are small and immature. ${ }^{67}$ There may be immunological advantages in this $^{89}$ but the uncertainties of nutrient composition lead to difficulties in clinical management. These are likely to be aggravated by the present practice of encouraging the exclusive use of the mother's own milk if possible ${ }^{\mathbf{1 0}}$ since the variations in a single source of breast milk are likely to be greater than in pooled samples.

Most breast milk fed to preterm infants is obtained by manual expression or by the use of a breast pump. There have been many reports of the composition of milk obtained in this way but few have examined the changes which occur in longitudinal samples, or have analysed the cross-sectional variability with reference to the needs of preterm infants. The purpose of this paper is to report the composition of breast milk obtained by standard technique in a group of mothers during the first 5 weeks of lactation, and to examine its adequacy as a source of nutrients for preterm infants.

\section{Materials and methods}

Breast milk samples were obtained from healthy mothers of term infants on the 1st, 3rd, 5th, 8th, 15 th, 22nd, 29th, and 36th days of lactation. The first day of lactation was defined as the first day of production of transitional milk, and was either the second or third day after delivery. All the mothers breast fed their babies, but on the study days they completely expressed both breasts into sterile containers at each feed using an electric breast pump. An aliquot was removed immediately for analysis and the remainder fed to the baby as required. Samples from each 24-hour period were pooled and stored at $-20^{\circ} \mathrm{C}$ until analysed.

Analyses of energy, osmolality, and dry weight were performed on whole milk samples. Energy was measured on freeze dried samples by ballistic bomb calorimetry. ${ }^{11}$ The bomb calorimeter was calibrated using sucrose. Osmolality was measured using an Advanced freezing point osmometer, Model $3 \mathrm{~W}$, calibrated with $\mathrm{NaCl}$. The $\mathrm{pH}$ of the milk samples was measured in $2 \mathrm{ml}$ homogenised samples using a radiometer $\mathrm{pH}$ meter equipped with an appropriate micro electrode.

Sodium, potassium, zinc, and copper were measured by atomic absorption spectrophotometry on a Pye Unicam SP9 spectrophotometer. A modification of the dilution method described for serum samples by Dawson and Walker ${ }^{12}$ was used. It was not possible to measure whole milk samples by 
this method, and the samples were therefore centrifuged at $2000 \mathrm{rev} / \mathrm{min}$ for 10 minutes to remove the fat, and all analyses were performed on skimmed milk (about $7 \%$ of the potassium, sodium, calcium, magnesium, and zinc is present in the fat and $11 \%$ of the copper). After centrifugation all the skimmed milk was removed and vortexed to ensure that no material had settled to the bottom of the tube. Samples were then diluted with deionised water as appropriate. All stages were followed with duplicate samples and also a water blank to ensure that there was no contamination. Analyses were repeated if there was a difference greater than $5 \%$ between duplicates. Samples for copper analysis were diluted 1 in 10 , for zinc 1 in 20 , for potassium 1 in 100 , and for sodium 1 in 100 or 1 in 1000 depending on the sodium concentrations of the sample. Standards of sodium, potassium, zinc, and copper nitrate were prepared daily.

Calcium was measured on duplicate samples of skimmed milk by a binding assay with orthocresol-phthalein using a Technicon AA2 system. The samples were prepared as described above and measured undiluted. Magnesium was measured on duplicate samples of skimmed milk on a Pye Unicam atomic absorption spectrophotometer using a continuous flow-through system. Samples were prepared as described above, and it was necessary to dilute samples with high magnesium concentration 1 in 2.

For the remaining analyses thawed samples were homogenised in a Dounce type normal tissue grinder and appropriate aliquots were immediately pipetted into the final reaction tubes to perform the different assays and isolation procedures.

Triglycerides were determined from $250 \mu \mathrm{l}$ portions of milk using a commercially available enzymatic test kit (Boehringer, Mannheim, FRG). Lipid extraction, determination of total phospholipids, and cholesterol assay were performed as described previously. ${ }^{13-15}$ Lactose was analysed enzymatically. $0.4 \mathrm{ml}$ milk was pipetted in $4 \mathrm{ml}$ deionised water and deproteinised by adding $0.1 \mathrm{ml}$ trichloroacetic acid (TCA) (3 mol/l). After a 10minute incubation period samples were neutralised using $\mathrm{NaOH}^{-}(0.25 \mathrm{ml}, 3 \mathrm{~mol} / \mathrm{l})$ and brought to a final volume of $20 \mathrm{ml}$ using deionised water. $0.1 \mathrm{ml}$ diluted and deproteinised milk samples were used for lactose analysis. Total protein was measured by the Lowry method. ${ }^{16}$ The validity of this method was previously confirmed by applying the microKjeldahl method to a series of human milk samples. Non-protein-nitrogen was calculated from the difference in total protein and TCA precipitable protein $\div 6.38$ (TCA concentration in the reaction mixture was $7.5 \%$ ).

\section{Results}

The results obtained for each sample were tabulated as shown in Table 1 for total protein. The mean concentration \pm standard deviation (SD) was estimated for each day for all components analysed, and the results are given in Tables $2 a$ and $2 b$.

The results of individual samples showed considerable variation both longitudinally (samples from the same mother on different days) and crosssectionally (between different mothers on the same day). Table 3 was therefore drawn up to examine the range of variation which occurred. Rows 1 and 2 give the absolute range, from the lowest concentration in any one sample to the highest concentration, estimated over the entire period studied. Results in rows 3 and 4 are restricted to samples obtained on or after day 8 , because before this time there is a rapid change in concentration of many components, as the milk changes from transitional to mature. After day 8 there are still changes in composition of the milk but at a reduced rate. Since preterm infants often receive pooled milk donated by mothers of term infants we examined the range of concentrations which might be found in pooled

Table 1 Concentration of total protein in breast milk $(\mathrm{g} / 100 \mathrm{ml})$

\begin{tabular}{|c|c|c|c|c|c|c|c|c|}
\hline \multirow[t]{2}{*}{ Mother } & \multicolumn{8}{|c|}{ Day of lactation } \\
\hline & 1 & 3 & 5 & 8 & 15 & 22 & 29 & 36 \\
\hline $\mathbf{A}$ & 3.66 & $1 \cdot 98$ & $1 \cdot 88$ & $1 \cdot 52$ & 1.49 & $1 \cdot 4$ & 1.42 & $1 \cdot 4$ \\
\hline B & $3 \cdot 07$ & $2 \cdot 16$ & 2.0 & $2 \cdot 2$ & $2 \cdot 58$ & 1.99 & $1 \cdot 78$ & $1 \cdot 78$ \\
\hline C & $2 \cdot 14$ & $1 \cdot 83$ & $1 \cdot 75$ & $1 \cdot 82$ & $1 \cdot 47$ & 1.49 & 1.48 & $1 \cdot 5$ \\
\hline D & $2 \cdot 54$ & 2.02 & 1.91 & $1 \cdot 82$ & 1.6 & $1 \cdot 66$ & - & $1 \cdot 2$ \\
\hline E & $2 \cdot 02$ & 1.87 & $1 \cdot 53$ & 1.42 & $1 \cdot 2$ & 1.75 & $1 \cdot 82$ & - \\
\hline $\mathbf{F}$ & $3 \cdot 94$ & $2 \cdot 07$ & 2.09 & $1 \cdot 74$ & 1.44 & 1.63 & 1.56 & $1 \cdot 82$ \\
\hline $\mathbf{G}$ & $4 \cdot 6$ & $2 \cdot 32$ & $1 \cdot 7$ & 1.69 & $1 \cdot 33$ & $1 \cdot 3$ & - & $1 \cdot 16$ \\
\hline $\mathbf{H}$ & $2 \cdot 2$ & 1.93 & $1 \cdot 66$ & 1.63 & $1 \cdot 43$ & $1 \cdot 4$ & $1 \cdot 48$ & $1 \cdot 29$ \\
\hline I & $2 \cdot 79$ & $2 \cdot 15$ & $2 \cdot 14$ & 2.06 & $1 \cdot 79$ & 1.48 & $1 \cdot 56$ & $1 \cdot 37$ \\
\hline $\mathbf{J}$ & $2 \cdot 58$ & $1 \cdot 53$ & $1 \cdot 56$ & $1 \cdot 35$ & $1 \cdot 26$ & $1 \cdot 0$ & 0.94 & 1.08 \\
\hline Mean & 2.95 & 1.99 & $1 \cdot 82$ & $1 \cdot 73$ & $1 \cdot 56$ & $1 \cdot 51$ & $1 \cdot 5$ & $1 \cdot 4$ \\
\hline SD & 0.86 & 0.22 & $0 \cdot 21$ & 0.27 & 0.4 & 0.27 & 0.27 & 0.26 \\
\hline
\end{tabular}


samples of milk. This was determined by taking the mean value of 4 milk samples with the lowest concentration of each component and the 4 samples with the highest concentrations. Thus the concentration of components in pooled milk is likely to lie between these limits.

Results in rows 5 and 6 are also taken from data obtained on or after day 8. Since one sample was not necessarily representative of all the milk produced by any one mother, a longitudinal mean was estimated from samples produced on days $8,15,22,29$, and 36 by each mother. This gave the average composition of milk produced by each mother during this period.

Rows 5 and 6 give the minimum and maximum values \pm SD from the 10 mothers, for each component analysed.

A small preterm infant weighing $1000 \mathrm{~g}$ would receive about $180 \mathrm{ml}$ of milk a day. We therefore examined the results with reference to the concentration of nutrients that such an infant would receive daily. The results are shown in Table 4. Using the figures obtained for mean values of pooled milk from Table 2, we estimated the lowest and highest concentrations which would be obtained daily by a

Table 2a Concentration of milk components (mean $\pm S D$ )

\begin{tabular}{|c|c|c|c|c|c|c|c|c|}
\hline Day & $\begin{array}{l}T C A \\
\text { protein } \\
(\mathrm{g} / 100 \mathrm{ml})\end{array}$ & $\begin{array}{l}\text { Total } \\
\text { protein } \\
(\mathrm{g} / 100 \mathrm{ml})\end{array}$ & $\begin{array}{l}\text { Non-protein } \\
\text { nitrogen } \\
(\mathrm{g} / 100 \mathrm{ml})\end{array}$ & $\begin{array}{l}\text { Lactose } \\
(\mathrm{g} / 100 \mathrm{ml})\end{array}$ & $\begin{array}{l}\text { Triglycerides } \\
(\mathrm{g} / 100 \mathrm{ml})\end{array}$ & $\begin{array}{l}\text { Phospholipids } \\
\text { (mg/100 ml) }\end{array}$ & $\begin{array}{l}\text { Cholesterol } \\
(\mathrm{mg} / 100 \mathrm{ml})\end{array}$ & $\begin{array}{l}\text { Energy } \\
(\text { kcal/100 ml })\end{array}$ \\
\hline $\begin{array}{r}1 \\
3 \\
5 \\
8 \\
15 \\
22 \\
29 \\
36\end{array}$ & $\begin{array}{l}2.31 \pm 0.64 \\
1.62 \pm 0.17 \\
1.41 \pm 0.25 \\
1.38 \pm 0.28 \\
1.24 \pm 0.38 \\
1.22 \pm 0.24 \\
1.23 \pm 0.25 \\
1.09 \pm 0.29\end{array}$ & $\begin{array}{l}2.95 \pm 0.86 \\
1.99 \pm 0.22 \\
1.82 \pm 0.21 \\
1.73 \pm 0.27 \\
1.56 \pm 0.42 \\
1.51 \pm 0.27 \\
1.5 \pm 0.27 \\
1.4 \pm 0.26\end{array}$ & $\begin{array}{l}0.1 \pm 0.07 \\
0.06 \pm 0.02 \\
0.06 \pm 0.02 \\
0.05 \pm 0.01 \\
0.05 \pm 0.01 \\
0.05 \pm 0.03 \\
0.05 \pm 0.03 \\
0.05 \pm 0.03\end{array}$ & $\begin{array}{l}4.07 \pm 0.98 \\
4.98 \pm 0.76 \\
5.13 \pm 0.54 \\
5.38 \pm 0.97 \\
5.42 \pm 0.76 \\
5.34 \pm 0.96 \\
4.01 \pm 1.13 \\
5.34 \pm 1.31\end{array}$ & $\begin{array}{l}2.14 \pm 0.86 \\
3.01 \pm 0.77 \\
3.06 \pm 0.45 \\
3.73 \pm 0.7 \\
3.59 \pm 0.86 \\
3.87 \pm 0.68 \\
4.01 \pm 1.13 \\
4.01 \pm 1.2\end{array}$ & $\begin{array}{l}39.08 \pm 11.44 \\
40.24 \pm 8.24 \\
39.46 \pm 4.49 \\
44.79 \pm 8.23 \\
39.73 \pm 11.27 \\
40.44 \pm 8.4 \\
41.26 \pm 9.41 \\
40.67 \pm 12.46\end{array}$ & $\begin{array}{l}36.64 \pm 15.03 \\
30.29 \pm 8.36 \\
27.03 \pm 3.97 \\
27.47 \pm 9.04 \\
23.64 \pm 8.95 \\
22.11 \pm 6.03 \\
22.61 \pm 5.53 \\
22.76 \pm 6.54\end{array}$ & $\begin{array}{l}55 \pm 5 \cdot 24 \\
60 \pm 7 \cdot 95 \\
63 \pm 4 \cdot 89 \\
64 \pm 4 \cdot 89 \\
63 \pm 10 \cdot 23 \\
63 \pm 5 \cdot 52 \\
61 \pm 6 \cdot 63 \\
61 \pm 9 \cdot 06\end{array}$ \\
\hline
\end{tabular}

Table 2b Measurements of $p H$, osmolality, minerals, and trace elements (mean $\pm S D$ )

\begin{tabular}{|c|c|c|c|c|c|c|c|c|}
\hline Day & $p H$ & $\begin{array}{l}\text { Osmolality } \\
\text { (mosmol/kg) }\end{array}$ & $\begin{array}{l}\text { Sodium } \\
(\mathrm{mg} / \mathrm{l} 00 \mathrm{ml})\end{array}$ & $\begin{array}{l}\text { Potassium } \\
(\mathrm{mg} / 100 \mathrm{ml})\end{array}$ & $\begin{array}{l}\text { Magnesium } \\
(\mathrm{mg} / 100 \mathrm{ml})\end{array}$ & $\begin{array}{l}\text { Calcium } \\
(\mathrm{mg} / 100 \mathrm{ml})\end{array}$ & $\begin{array}{l}\text { Copper } \\
(\mu \mathrm{g} / 100 \mathrm{ml})\end{array}$ & $\begin{array}{l}\text { Zinc } \\
(\mu \mathrm{g} / 100 \mathrm{ml})\end{array}$ \\
\hline $\begin{array}{r}1 \\
3 \\
5 \\
8 \\
8 \\
15 \\
22 \\
29 \\
36\end{array}$ & $\begin{array}{l}7.6 \pm 0.32 \\
7.6 \pm 0.52 \\
7.4 \pm 0.52 \\
7.1 \pm 0.54 \\
7.0 \pm 0.58 \\
7.0 \pm 0.59 \\
7.2 \pm 0.68 \\
7.1 \pm 0.73\end{array}$ & $\begin{array}{l}293 \pm 7 \cdot 55 \\
293 \pm 6 \cdot 82 \\
288 \pm 7 \cdot 61 \\
291 \pm 7 \cdot 65 \\
283 \pm 12 \cdot 11 \\
286 \pm 12 \cdot 09 \\
289 \pm 5 \cdot 1 \\
289 \pm 3 \cdot 45\end{array}$ & $\begin{array}{l}63 \cdot 5 \pm 28 \cdot 7 \\
43.9 \pm 14 \cdot 7 \\
36 \cdot 7 \pm 17.2 \\
40.9 \pm 31 \cdot 3 \\
25 \cdot 0 \pm 11 \cdot 1 \\
29.8 \pm 18 \cdot 1 \\
39.3 \pm 36.4 \\
33.6 \pm 20.8\end{array}$ & $\begin{array}{l}62 \cdot 8 \pm 13 \cdot 9 \\
72 \cdot 1 \pm 9 \cdot 4 \\
71 \cdot 4 \pm 10 \cdot 2 \\
64 \cdot 3 \pm 8 \cdot 6 \\
59 \cdot 3 \pm 10 \cdot 4 \\
54 \cdot 7 \pm 7 \cdot 7 \\
54 \cdot 3 \pm 8 \cdot 9 \\
54 \cdot 3 \pm 7 \cdot 3\end{array}$ & $\begin{array}{l}3.25 \pm 0.73 \\
3.69 \pm 0.75 \\
3.62 \pm 0.75 \\
3.79 \pm 1.29 \\
3 \cdot 38 \pm 1 \cdot 14 \\
3 \cdot 11 \pm 0.92 \\
3 \cdot 35 \pm 1.06 \\
3.47 \pm 1.12\end{array}$ & $\begin{array}{l}23.52 \pm 7.28 \\
23.0 \pm 5.96 \\
23.04 \pm 5.84 \\
21.08 \pm 4.92 \\
18.56 \pm 4.16 \\
17.94 \pm 3.44 \\
17.24 \pm 5.0 \\
17.8 \pm 6.22\end{array}$ & $\begin{array}{l}41 \cdot 98 \pm 5 \cdot 84 \\
47.76 \pm 12.16 \\
48 \cdot 18 \pm 10 \cdot 88 \\
43 \cdot 13 \pm 13.45 \\
43.89 \pm 12.74 \\
39.56 \pm 12.38 \\
35.34 \pm 10.91 \\
34.42 \pm 9.26\end{array}$ & $\begin{array}{l}775 \pm 133 \\
451 \pm 132 \\
390 \pm 123 \\
332 \pm 127 \\
281 \pm 116 \\
233 \pm 131 \\
171 \pm 115 \\
171 \pm 92\end{array}$ \\
\hline
\end{tabular}

Table 3 Range of variation of milk components during lactation (see text)

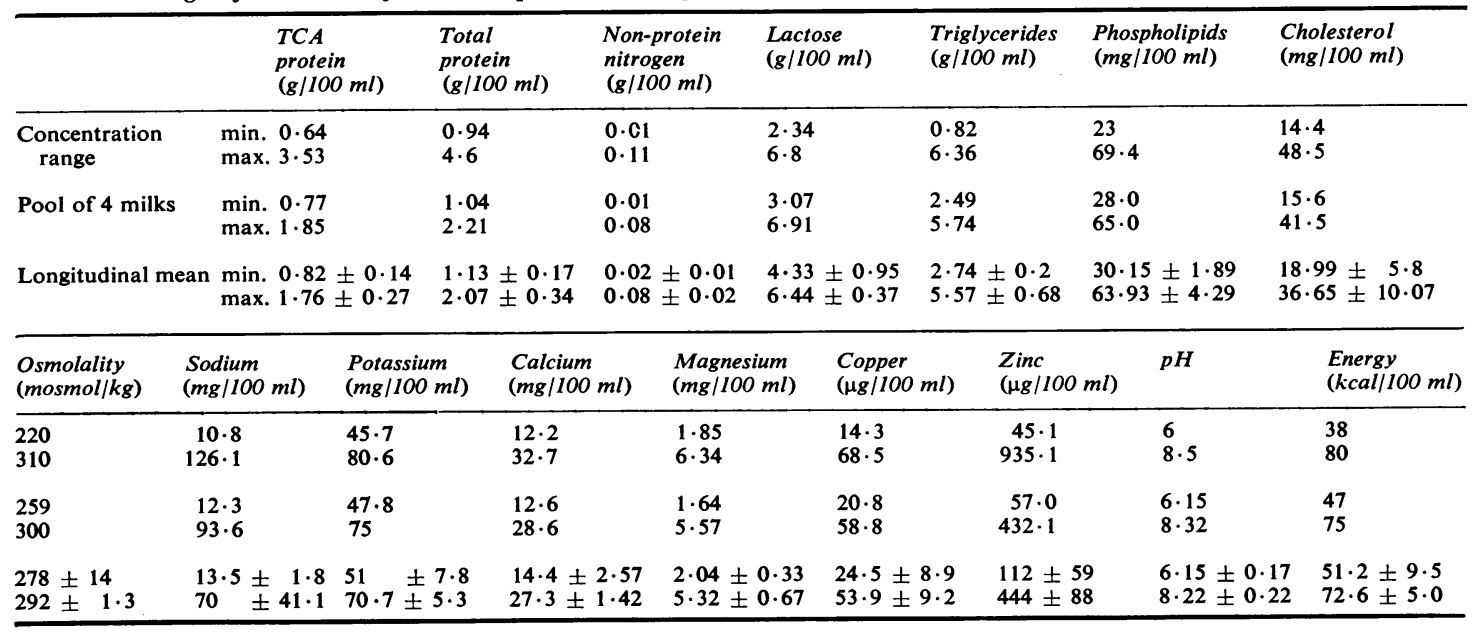


$1000 \mathrm{~g}$ baby receiving $180 \mathrm{ml}$ milk. Also shown is the recommended daily intake of nutrients for which data are available, for a $1000 \mathrm{~g}$ baby.

\section{Discussion}

The milk analysed in this study was collected by a standardised procedure designed to minimise variations between samples caused by the time of collection or differences between fore milk and hind milk. The method of collection used was the same as that followed by mothers who express milk for a milk bank, or for feeding to their own infants who are too ill or too small to suckle; therefore the milk analysed in this study was identical with that which would be received by infants in such circumstances.

The most striking feature of the results was that there was a large degree of variation in composition between samples. Because of the careful standardisation of collection procedures we believe the variation in results reflects the variable composition of breast milk as it is expressed.

Results in Table 3 show the range of values obtained for milk composition during the period of study. It can be seen that in nearly every case, the maximum value obtained was more than twice the minimum, and in the case of triglyceride content the maximum was 8 times the level of the minimum. In some cases, such as protein concentration and sodium and zinc content, there is known to be a rapid decrease in concentrations during the first week of lactation, from the high levels in colostrum and transitional milk to lower levels in mature milk; thus in a study of samples over a period from the onset of lactation to the 36th day there would be expected to be a large difference between samples obtained at the beginning and end of the period as can be seen in the first two rows of Table 2. For this reason the remaining rows in Table 2 consider only results obtained on or after day 8 ; there was however still considerable variation in the zinc and sodium content of samples during this latter part of the study period.

Examination of the longitudinal mean \pm SD for each mother in the final row of Table 3 showed that although there was variation between samples obtained from any one mother this was not as great as the variation between samples from different mothers on the same day of lactation (Table 2).

If we consider the needs of the preterm infant, it is known that human milk may satisfy a number of important criteria - such as protein and fat digestibility ${ }^{17}$ and the immunity conferred by antibodies and leucocytes present in breast milk. ${ }^{9}$ However, because of the varying nature of breast milk composition demonstrated here and by others ${ }^{217-19}$ it 
may not satisfy the nutrient needs demanded by a fast growing preterm infant. From the figures for the requirements of a fetus in the last trimester of pregnancy (Table 4) it can be seen that all samples of breast milk fall short of the requirements for calcium and magnesium, and a proportion are inadequate in protein, copper, and zinc. Some milks however, provide an excess of nutrients which may be damaging to the immature digestive and metabolic systems of a preterm infant.

In conclusion, milk samples obtained by standardised collection procedures were analysed to determine how the composition develops and changes during the first 5 weeks of lactation. Considerable variation was observed both between subjects and between samples taken from the same mother. Since milk expressed in this way is often fed to preterm infants, either from pooled samples in a milk bank, or from individual samples, we have considered this variation in relation to the requirements of a preterm infant. Results suggest that even with pooled samples it would be difficult to obtain standardised feeds of human milk, and without analysis it would be impossible to predict whether an infant was receiving adequate concentrations of essential nutrients, or whether some were present in a dangerously high concentration.

It would therefore be ideal to provide some form of quality control for milk donated to milk banks to ensure that the major nutrients were present in concentrations suitable for the needs of the infants receiving the milk.

We thank Dr I R F Brown and Elsa Hutchinson for help with the analyses, and Professor O Humke, Dr G Linke, Dr E Lattermann, Dr O Ruff, and Dr Werner for help with collection of milk samples.

\section{References}

1 Macy I G. Composition of human colostrum and milk. Am J Dis Child 1949; 78: 589-603.

2 Vaughan L A, Weber C W, Kemberling S R. Longitudinal changes in the mineral content of human milk. Am J Clin Nutr 1979; 32: 2301-6.

3 Picciano M F, Guthrie H A. Copper, iron, and zinc contents of mature human milk. Am J Clin Nutr 1976; 29: 242-54.

4 Barrie H, Martin E, Ansell C. Milk for babies. Lancet 1975 ; i: $1330-1$.

5 Gibbs J H, Fisher C, Bhattacharya S, Goddard P, Baum J D. Drip breast milk: its composition, collection, and pasteurization. Early Hum Dev 1977; 1 : 227-45.

- Stevens L H. Appraisal of the state of nutrition of babies of low birthweight. I. Current status. Aust Paediatr $J$ $1970 ; 6: 70-5$.

7 Räihä N C R, Heinonen K, Rassin D K, Gaul D E. Milk protein quantity and quality in low birthweight infants. 1. Metabolic responses and effects on growth. Pediatrics 1976; 57: 659-74.

8 Barlow B, Santulli T V, Heird W C, Pitt J, Blanc W A, Schullinger $H$. An experimental study of acute neonatal enterocolitis: the importance of breast milk. $J$ Pediatr Surg 1974; 9: 587-95.

9 Hanson L $\AA$, Winberg J. Breast milk and defence against infection in the newborn. Arch Dis Child 1972; 47: 845-8.

10 Department of Health and Social Security. The collection and storage of human milk. Report on Health and Social Subjects No 22. London: HMSO, 1981.

11 Miller D S, Payne P R. A ballistic bomb-calorimeter. Br J Nutr 1975; 13: 501-8.

12 Dawson J B, Walker B E. Direct determination of zinc in whole blood, plasma, and urine by atomic absorption spectroscopy. Clin Chim Acta 1969; 26: 465-75.

13 Gentner P R, Bauer M, Dieterich I. Thin layer chromatography of phospholipids. Separation of major phospholipid classes of milk without previous isolation from total lipid extracts. J Chromatogr 1981; 206: 200-4.

14 Gentner P R, Haasemann A. Methode zur enzymatischen Cholesterin-Bestimmung in Milchproben unter Verwendung kommerziell erhältlichen Testkombination. Milchwissenschaft 1979; 34: 344-6.

15 Gentner P R, Haasemann A. Phosphorometrie-Eine Methode zur schnellen quantitativen Bestimmung von Phospholipiden nach dünnschichtchromatographischer Trennung. Fette Seifen Anstrichmittel 1979; 81 : 357-60.

16 Lowry D H, Rosebrough N J, Farr A C, Randells R I. Protein measurement with the folin phenol reagent. $J$ Biol Chem 1951; 193: 265-81.

17 Fleischman A R, Finberg L. Breast milk for term and premature infants-optimal nutrition? Semin Perinatol $1979 ; 3: 397-405$.

18 Fomon S J, Ziegler E E, Vazquez H D. Human milk and the small premature infant. Am J Dis Child 1977; 131: 463-7.

19 Davies D P. Adequacy of expressed breast milk for early growth of preterm infants. Arch Dis Child 1977; 52: 296-301.

20 Cockburn F. Metabolism and nutrition. In: Cockburn F, Drillien C M, eds. Neonatal medicine. Oxford: Blackwell, 1974: 260-303.

${ }^{21}$ Fomon S J, Ziegler E E, O'Donnell A M. Infant feeding in health and disease. In: Fomon $\mathrm{S} J$, ed. Infant nutrition, second edition. Philadelphia: Saunders, 1974: 498.

22 Fanaroff $A$, Klaus $M$ H. The gastrointestinal tract feeding and selected disorders. In: Klaus $\mathbf{M} \mathbf{H}$, Fanaroff A A, eds. Care of the high risk neonate. Philadelphia: Saunders, 1979: 113-45.

23 Widdowson E M. Nutrition. In: Davis J, Dobbing J, eds. Scientific foundations of paediatrics. London: Heinemann, 1974: 44-55.

24 Widdowson E M, Spray C M. Chemical development in utero. Arch Dis Child 1951 ; 26: 205-14.

25 Paxson C L, Jr. Growth and nutrition. In: Paxson C L, $\mathrm{Jr}$, ed. Van Leeuwen's newborn medicine. Chicago: Year Book Medical Publishers, 1979: 452-77.

Correspondence to Dr O G Brooke, Department of Child Health, St George's Hospital Medical School, Cranmer Terrace, London SW17 0RE.

Received 1 February 1982 